\title{
Epidemiological investigation of non-albicans Candida species recovered from mycotic mastitis of cows in Yinchuan, Ningxia of China
}

\author{
Jun Du ${ }^{1,2}$, Xiaoyu Wang ${ }^{1,2}$, Huixia Luo ${ }^{1,2}$, Yujiong Wang ${ }^{1,2^{*}}$, Xiaoming Liu I $^{1,2^{*}}$ (D) and Xuezhang Zhou ${ }^{1,2^{*}}$
}

\begin{abstract}
Background: Candida spp. is the vital pathogen involved in mycotic mastitis of cows. However the epidemiology and infection of Candida species in mycotic mastitis of cow in Ningxia province of China has not been explored. In the present study, the epidemiology, antimicrobial susceptibility and virulence-related genes of non-albicans Candida (NAC) species were investigated.

Methods: A total of 482 milk samples from cows with clinical mastitis in four herds of Yinchuan, Ningxia were collected and used for the isolation and identification of mastic pathogens by phenotypic and molecular characteristics, and matrix-assisted laser desorption ionization-time of flight mass spectrometry. The antimicrobial susceptibility to antifungal agents was also determined by a disk diffusion assay. The presence of virulence-related genes was determined by polymerase chain reaction (PCR).

Results: A total of 60 isolates from nine different Candida species were identified from 256 (60/256, 23.44\%) milk samples. The most frequently identified species in cows with clinical mastitis groups were Candida krusei $(n=14)$ and Candida parapsilosis $(n=6)$. Others include Candida lipolytica, Candida lusitaniae, Cryptococcus neoformans. But no Candida albicans was identified in this study. Interestingly, All C. krusei isolates (14/14) were resistant to fluconazole, fluorocytosine, itraconazole and ketoconazole, 2 out of 14 C. krusei were resistant to amphotericin, and 8 out of the 14 were resistant to nystatin. Similarly, all six C. parapsilosis isolates were resistant to fluorocytosine, but susceptible to fluconazole, ketoconazole and nystatin; two of the six were resistant amphotericin and itraconazole. Molecularly, all of the C. parapsilosis isolates carried eight virulence-related genes, FKS1, FKS2, FKS3, SAP1, SAP2, CDR1, ERG11 and MDR1. All of the C. krusei isolates contained three virulence-related genes, ERG11, ABC2 and FKS1.
\end{abstract}

Conclusion: These data suggested that Candida species other than C. albicans played a pathogenic role in mycotic mastitis of cows in Yinchuan, Ningxia of China. The high incidence of drug-resistant genes in C. parapsilosis and C. krusei also highlighted a great concern in public and animal health in this region.

Keywords: Mycotic mastitis, Candida parapsilosis, Candida krusei, Antimicrobial susceptibility, Virulent gene

\footnotetext{
*Correspondence: wyj@nxu.edu.cn; Ixm1966@nxu.edu.cn;

zhouxuezhang@nxu.edu.cn

${ }^{1}$ Key Laboratory of the Ministry of Education for the Conservation and

Utilization of Special Biological Resources of Western China, Ningxia

University, Yinchuan 750021, Ningxia, China

Full list of author information is available at the end of the article
}

(c) The Author(s). 2018 Open Access This article is distributed under the terms of the Creative Commons Attribution 4.0 International License (http://creativecommons.org/licenses/by/4.0/), which permits unrestricted use, distribution, and reproduction in any medium, provided you give appropriate credit to the original author(s) and the source, provide a link to the Creative Commons license, and indicate if changes were made. The Creative Commons Public Domain Dedication waiver (http://creativecommons.org/publicdomain/zero/1.0/) applies to the data made available in this article, unless otherwise stated. 


\section{Background}

Cow mastitis is a disease caused by infections of a variety of microorganisms, which causes large economical looses and damages to the breeding industry by decreasing milk productivity and increasing costs of antibiotic treatments and culling [1]. In most cases, fungal infections of the mammary gland are mostly caused by yeast, the main genus of which is Candida [2]. Mastitis infections caused by fungi of the Candida genus have long been known in animals, and Candida-caused mycotic mastitis was firstly described by Fleischer in 1930 [3]. In this regard, Candida species are considered as opportunistic pathogens that colonize the cow udder. In addition, the harness and abuse of antibacterial agents, and treatments of contaminated antibiotic solutions, as well as duct, or other materials brought in contact with the mammary gland also favor yeast colonization in cow udders [4].

Recently, a large number of virulent factors have been found in C. parapsilosis and C. krusei originated from cow mastitis, including the Fksp subunits of the 3-1,3-D-glucan synthase enzyme (FKS1, FKS2, and FKS3), aspartyl proteinases (SAPP1 and SAPP2), the ATP binding cassette $(\mathrm{ABC})$ transporters, Candida drug resistance gene 1 (CDR1), major facilitator superfamily (MFS) transporter multiple drug resistance gene 1 (MDR1), 14 $\alpha$-demethylases (ERG11), efflux pump transporters (ABC1 and ABC2). These factors favor the survival and growth of Candida spp. in the mammary gland of cows.

The dairy industry is a predominant economics in Ningxia, a province in Western China. The mastitis of cows causes a significant economic loss in this region every year. It has been well documented that mycotic mastitis is an important causation of economic loss to the dairy industry, however the epidemiology of pathogens may vary in different areas. In this respect, there is a paucity of information about antimicrobial resistance and virulent factors of $C$. parapsilosis and C. krusei isolates in Ningxia of China, the aim of the present study is therefore to interrogate the epidemiology of fungal infection, and the antimicrobial susceptibility and virulence-related genes of Candida spp. in Yinchuan, Ningxia of China.

\section{Methods}

\section{Isolation and identification of pathogens}

This study was submitted to and approved by the Ethics Committee of Animal Study in Ningxia University. A total of 482 milk samples were collected from the cows with clinical mastitis, which originated from four herds in Yinchuan of Ningxia province, China. Clinical mastitis was defined by swelling, reduced milk flow, and abnormal milk appearance (watery to viscous with clots varying from gray-white to yellowish). Additionally, other signs of infection such as fever, inappetence, ataxia, and depression were also considered. The samples were first plated onto the Sabouraud dextrose broth and incubated at $37{ }^{\circ} \mathrm{C}$ for $48 \mathrm{~h}$. The cultures were identified by morphological characteristics (formation of chlamydoconidium, pseudohyphae and germinal tube development), Gram staining, biochemical tests (growth in the presence of $0.1 \%$ cyclohexamide (SigmaTM), acidic pH tolerance, urea hydrolysis and carbohydrates assimilation and/or fermentation) and CHROMagar Candida culture [5]. All presumptive Candida species isolates were further confirmed by Matrix- assisted laser desorption ionization-time of flight mass spectrometry (MALDI-TOF MS) $\left(\right.$ VITEK $^{\oplus}$ MS, BioMerieux, France).

\section{Antimicrobial susceptibility tests}

The antimicrobial susceptibility was determined by disk diffusion method according to the guideline of the Clinical Laboratory Standards Institute for antifungal susceptibility $[6,7]$. A total of six antimicrobial agents were used to evaluate the antimicrobial resistance of the isolates, which included fluorocytosine $(1 \mu \mathrm{g} /$ disk $)$, itraconazole $(10 \mu \mathrm{g} /$ disk), ketoconazole (15 $\mu \mathrm{g} /$ disk), fluconazole ( $25 \mu \mathrm{g} /$ disk), nystatin $(50 \mu \mathrm{g} /$ disk), amphotericin $(10 \mu \mathrm{g} /$ disk $)$. Results were recorded as resistant, intermediate and sensitive. The C. parapsilosis ATCC 22019 strain and C. krusei ATCC 6258 strain were used as references for $C$. parapsilosis strain and C. krusei, respectively.

\section{Detection of virulence-related genes}

The presence of virulence-related genes in C. parapsilosis and C. krusei isolates was detected by a PCR assay. The genes of interest, primer sequences, and expected size of fragment of PCR products were given in Tables 1 and 2 . The PCR reactions were performed in a final volume of $25 \mu \mathrm{L}$ of reaction mixture consisted of $50 \mathrm{ng}$ of genomic DNA, 20 pmol of each primer, and $12.5 \mu \mathrm{L}$ of $2 \times$ Taq PCR MasterMix containing $0.1 \mathrm{U}$ of Taq polymerase $/ \mu \mathrm{L}, 0.5 \mathrm{mM}$ dNTP each, $20 \mathrm{mM}$ Tris- $\mathrm{HCl} /$ $\mathrm{pH} 8.3,100 \mathrm{mM} \mathrm{KCl}, 3 \mathrm{mM} \mathrm{MgCl}$ (Tiangen Biotech, Beijing, China). The cycling conditions were as following: an initial denaturation at $94{ }^{\circ} \mathrm{C}$ for $3 \mathrm{~min} ; 30$ cycles of denaturation at $94{ }^{\circ} \mathrm{C}$ for $30 \mathrm{~s}$, annealing at distinct temperature (Tables 1 and 2) for $30 \mathrm{~s}$, and primer extension at $72{ }^{\circ} \mathrm{C}$ for $1 \mathrm{~min}$; and a final extension at $72{ }^{\circ} \mathrm{C}$ for $6 \mathrm{~min}$.

\section{Results}

Isolation and identification of COW mastitis pathogens

Total of 256 pathogenic yeasts were isolated from 482 milk samples collected from cows with clinical mastitis $(256 / 482,53.1 \%)$ in Yinchuan of Ningxia province. Among them, 60 (60/256, 23.44\%) were identified in nine of Candida species, in which the C. krusei $(23.33 \%$, 
Table 1 The PCR primers for amplification of C. parapsilosis virulence genes

\begin{tabular}{|c|c|c|c|}
\hline Gene & Primer sequence ${ }^{a}\left(5^{\prime}-3^{\prime}\right)^{a}$ & $\begin{array}{l}\text { Annealing } \\
\text { temperature }\end{array}$ & Reference \\
\hline \multirow[t]{2}{*}{ FKS1 } & F: ATCCAAGATCTTCCGGTGCCTCAA & $60^{\circ} \mathrm{C}$ & [8] \\
\hline & R: ATCAGCTGACCATGCTGGATATGG & & \\
\hline \multirow[t]{2}{*}{ FKS2 } & F: AATGGGCAGAGGTTGAGAAGGTAG & $60^{\circ} \mathrm{C}$ & \\
\hline & R: GGGTTCCAAGCAGGATATGGATCA & & \\
\hline \multirow[t]{2}{*}{ FKS3 } & F: TCGTAGGTTCGAATCCTGCTGAGA & $60^{\circ} \mathrm{C}$ & \\
\hline & R: ATGGTGAAGGCGCAACGGTGTAAA & & \\
\hline \multirow[t]{2}{*}{ SAPP1 } & F: ACTGGACAACAAATTGCAGATG & $57^{\circ} \mathrm{C}$ & [9] \\
\hline & R: TAAACTGCTTCATTGCTGGTGT & & \\
\hline \multirow[t]{2}{*}{ SAPP2 } & F: GTCATATGGGGGATTTGCAC & $57^{\circ} \mathrm{C}$ & \\
\hline & R: CGCTTTGCTGATGTTACCAG & & \\
\hline \multirow[t]{2}{*}{ MDR1 } & F: TTCGTGATAGTTITGGTGGTAG & $62^{\circ} \mathrm{C}$ & [10] \\
\hline & R: TGAACCTGGAGTGAATCTTGT & & \\
\hline \multirow[t]{2}{*}{ CDR1 } & F: ATTTGCCGACATCCACCGTTAGG & $60^{\circ} \mathrm{C}$ & [11] \\
\hline & R: ACCATGCTGTTTGCGAGTCCA & & \\
\hline \multirow[t]{2}{*}{ ERG11 } & F: GTACACCGTCATTACTCTACCCAACA & $62^{\circ} \mathrm{C}$ & \\
\hline & R: TGCTCCTTTCATTTACAACATCATTT & & \\
\hline
\end{tabular}

${ }^{\mathrm{a}} F$ forward, $R$ reverse

14/60) and C. parapsilosis $10 \%$ (6/60) were two of the most frequent Candida species. In addition, $16.66 \%$ isolates (10/60) were classified as Candida-like species. Other identified Candida species included Candida lipolytica (5/60, 8.33\%), Candida lusitaniae (5/60, 8.33\%), Candida rugosa (4/60, 6.67\%), Trichosporon mucoides (4/60, 6.67\%), Candida sphaerica (3/60, 5\%), Candida tropicalis (3/60, 5\%) and Candida utilis (3/60, 5\%).

CHROMagar Candida is a differential culture medium that allows selective isolation of yeasts and simultaneously identifies colonies of C. albicans, C. krusei, and other Candida spp. Results of this study confirm the accuracy of CHROMagar in providing a presumptive identification of C. krusei and C. parapsilosis, which was consistent with Odds and Bernaerts study [8]. These

Table 2 The PCR primers for amplification of C. krusei virulence genes

\begin{tabular}{|c|c|c|c|}
\hline Gene & Primer sequence ${ }^{a}\left(5^{\prime}-3^{\prime}\right)^{a}$ & $\begin{array}{l}\text { Annealing } \\
\text { temperature }\end{array}$ & Reference \\
\hline \multirow[t]{2}{*}{ FKS1 } & F: ACTGCATCGTTTGCTCCTCT & $63^{\circ} \mathrm{C}$ & [12] \\
\hline & R: GAACATGATCAATTGCCAAC & & \\
\hline \multirow[t]{2}{*}{$A B C 1$} & F: GATAACCATTTCCCACATTTGAGT & $60^{\circ} \mathrm{C}$ & [13] \\
\hline & R: CATATGTTGCCATGTACACTTCTG & & \\
\hline \multirow[t]{2}{*}{$A B C 2$} & F: CCTTITGTTCAGTGCCAGATTG & $60^{\circ} \mathrm{C}$ & \\
\hline & R: GTAACCAGGGACACCAGCAA & & \\
\hline \multirow[t]{2}{*}{ ERG11 } & F: ATTGCGGCCGATGTCCAGAGGTAT & $60^{\circ} \mathrm{C}$ & \\
\hline & R: GCGCAGAGTATAAGAAAGGAATGGA & & \\
\hline
\end{tabular}

${ }^{\mathrm{a}} F$ forward, $R$ reverse results of the preliminary identification on the CHROMagar Candida were agree with those by MALDI-TOF MS. C. krusei is the only species which grows on Sabouraud's dextrose agar as spreading colonies with a matt or a rough whitish yellow surface, in contrast to the convex colonies of other Candida spp. All 14 isolates of C. krusei tested formed colonies after $48 \mathrm{~h}$ of incubation at $37{ }^{\circ} \mathrm{C}$ on CHROMagar Candida that were typically pale pink, large, rough, flat, and spreading with broad white edges (Fig. 1a). Unlike C. krusei, all 6 isolates of C. parapsilosis formed white or faint yellow, small, papillae, smooth colony (Fig. 1b). In addition, C. krusei and $C$. parapsilosis are both usually found in two basic morphological forms, as yeast and pseudohyphae (Fig. 1a' and b'). Both were frequently present simultaneously in growing cultures and may not be separated easily.

\section{Antimicrobial susceptibility test}

The antimicrobial susceptibility test demonstrated that $C$. krusei and C. parapsilosis isolates from cow mastitis cases in Yinchuan of Ningxia province had a variable degree of resistance to the antimicrobials (Fig. 2a and b, Tables 3 and 4). C. krusei isolates were respectively resistant to fluconazole $(14 / 14,100 \%)$, fluorocytosine $(14 / 14,100 \%)$, itraconazole $(14 / 14,100 \%)$, ketoconazole $(14 / 14,100 \%)$, amphotericin $(2 / 14,14.3 \%)$, and nystatin $(8 / 14,57.1 \%)$ (Table 3). C. parapsilosis isolates were respectively resistant to fluorocytosine $(6 / 6,100 \%)$, amphotericin $(2 / 6$, $33.3 \%)$, itraconazole $(2 / 6,33.3 \%)$, but susceptible to fluconazole $(6 / 6,100 \%)$, ketoconazole $(6 / 6,100 \%)$, nystatin $(6 / 6,100 \%)$ (Table 4).

\section{Detection of Virulence-related Genes}

Three virulence-related genes in C. krusei and eight virulence-related genes in $C$. parapsilosis isolates were determined by PCR in the present study. The results indicated that all $(14 / 14,100 \%)$ C. krusei isolates contained the ERG11 gene, 12 out of 14 (85.7\%) C. krusei isolates were positive in $\mathrm{ABC} 2$ and $\mathrm{FKS} 1$ genes, but no $\mathrm{ABC} 1$ gene was detected in these C. krusei isolates (Fig. 3). All $(6 / 6,100 \%)$ C. parapsilosis isolates carried the FKS1, FKS2, FKS3, CDR1, ERG11, SAPP1 and SAPP2 genes; 4 out of the $6(66.7 \%)$ of $C$. parapsilosis isolates contained MDR1 gene (Fig. 4).

\section{Discussion}

In this study, Candida species of yeasts were isolated in the $23.44 \%(60 / 256)$ of all samples analyzed. This rate is a marginally higher than the rates reported in Turkey were $12.7 \%$ [9], $17.7 \%$ [10]; the rates reported in Brazil were $17.3 \%$ [4], 12.8\% [11]; and the rate reported in Slovenia was $7.5 \%$ [12]. C. krusei was the predominant species isolated in this study, which was $23.33 \%(14 / 60)$ of the Candida isolates from those with clinical mastitis. 


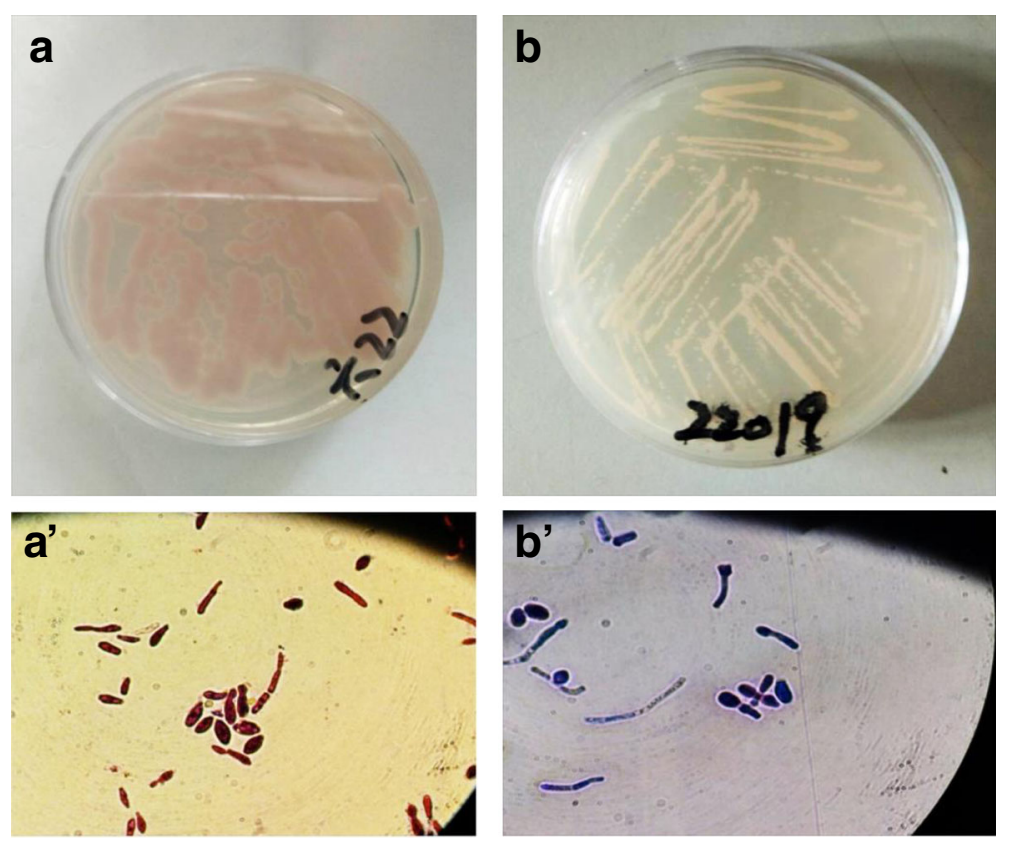

Fig. 1 Representative culture and Morphology of C. krusei and C. parapsilosis isolates. a Representative culture of C. krusei on CHROMagar plate; a' the morphology of Giemsa staining for yeast and pseudohyphae of a C. krusei isolate in $\mathbf{a}$; $\mathbf{b}$ Representative culture of C. parapsilosis on CHROMagar plate; b' the morphology of Giemsa staining for yeast and pseudohyphae of a C. parapsilosis isolate in (b)

However, there is some discrepancy among rates that were also reported by others. Pengov et al. reported a 34\% [12], De\&Marin et al. reported $a 44.5 \%$ [4], and Sartori et al. reported a $34.6 \%$ [11] of C. krusei isolates from cows with mastitis. Their data reported a higher frequency of C. krusei infection than findings in this report. However, the rate of $C$. krusei isolates of our finding was higher than others. Ruz-Peres et al. reported a 18.18\% [13], ErbaŞ et al. reported a $17.4 \%$ [10], Ksouri et al. reported a 15.57\% [14], Krukowski et al. reported a $15.5 \%$ [15], and Eldesouky et al. reported a $12.2 \%$ of C. krusei isolates in cow mastitis [16].

C. parapsilosis was the second most frequent Candida species in this study. Although often being considered less virulent than C. albicans, C. parapsilosis is the Candida species with the largest increase in clinical incidence in human beings in recent decades. In animals, $C$. parapsilosis are also of great importance in veterinary medicine because of their ability to infect many animal species, including cows $[14,17,18]$. Indeed, many studies have described the isolation of $C$. parapsilosis from milk samples with a frequency varied from $1.7 \%$ to up to $25.4 \%$, depending on the sanitary condition and environmental factors $[10,11,15,19]$.

The discrepancy in determination rates of Candida species among different geographic regions might be a consequence effect of several factors, such as the abuse of intramammary antibiotic treatment or the use of dairy
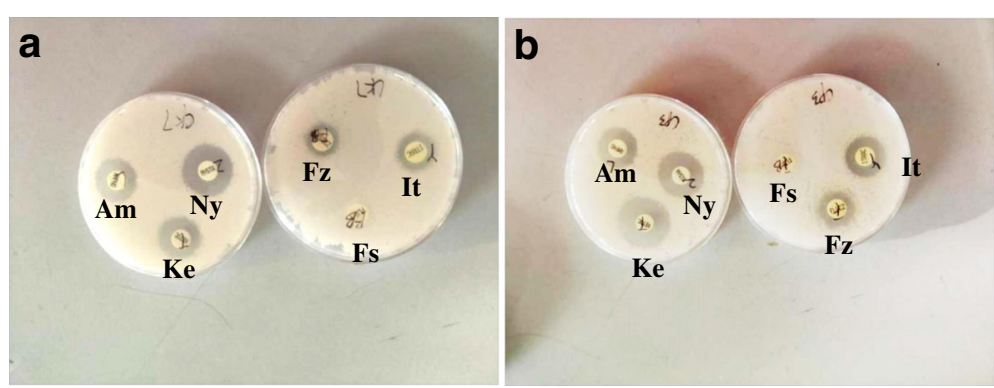

Fig. 2 Representative antimicrobial susceptibility tests by disk diffusion assay for C. krusei and C. parapsilosis isolates. a Representative disk diffusion assay for C. krusei isolate cultured on CHROMagar plate with indicated antimicrobial disks; $\mathbf{b}$ Representative disk diffusion assay for a C. parapsilosis isolate cultured on CHROMagar plate with indicated antimicrobial disks. Am, amphotericin; Fs, fluorocytosine; Fz, fluconazole; It, itraconazole; Ke, ketoconazole; Ny, nystatin 
Table 3 Results of antimicrobial susceptibility tests of C. krusei isolates ( $n=14)$

\begin{tabular}{lllll}
\hline Antibiotic & Resistant, \% (no.) & Intermediate, \% (no.) & Susceptible-dose dependent, SDD, \% (no.) & Susceptible, \% (no.) \\
\hline Amphotericin & $14.3(n=2)$ & $85.7(n=12)$ & 0 & 0 \\
Fluorocytosine & $100(n=14)$ & 0 & 0 & 0 \\
Fluconazole & $100(n=14)$ & 0 & 0 & 0 \\
Itraconazole & $100(n=14)$ & 0 & 0 & 0 \\
Ketoconazole & $100(n=14)$ & 0 & 0 & 0 \\
Nystatin & 0 & $42.9(n=6)$ & 0 & $57.1(n=8)$
\end{tabular}

farm made antibiotic infusions for mastitis treatments [15], yeast contaminated food or environment [20], inadequate sanitary practices of milking procedures, and the natural resistance to fluconazole of $C$. krusei [21, 22]. The relative cell-surface hydrophobicity $(\mathrm{CSH})$ of $C$. parapsilosis, adherence to host tissues and plastic surfaces such as milkers or other prosthetic materials [23-25], and the presence of pathogenic strains of C. krusei might also contribute the high rate of $C$. krusei and $C$. parapsilosis in milk samples of cow mastitis [26].

Of note, there was no C. albicans was identified in this study. This result was in accordance with the report by ErbaŞ et al. [10]. Although C. albicans was considered to be the most frequent cause of fungemia, a number of reports have documented infections caused by C. parapsilosis, C. krusei and other NAC species [27], suggesting that the pathogenic role of opportunistic NAC species in this disease. Therefore, it is a necessity to pay more attention in NAC species in order to establish the possible role in mycotic mastitis in the region of Yinchuan, Ningxia of China.

In this study, the antifungal resistance was also investigated. Notably, all of the six C. parapsilosis isolates (100\%) were resistant to fluorocytosine, and all 14 of $C$. krusei isolates (100\%) were resistant to ketoconazole, fluconazole, itraconazole and fluorocytosine. This finding was consistent with a study by Sonmez et al. [28], but was different from reports by others [29-31]. Of interest, these agents are the primary agents against the infection of Candida species. It has been reported that the resistance of $C$. albicans to fluorocytosine was up to 10-30\%, and the incidence of drug resistant NAC species was increased [10, 28]. For example, the natural or acquired resistance to fluconazole was confirmed in C. krusei and
C. glabrata [32]. Our finding in C. krusei also supported the results reported in literatures. It was worthy to note that C. krusei and C. parapsilosis isolates from cow mastitis cases in Ningxia region were more resistant to antifungal agents. It is strongly recommended that fluorocytosine, and other azole antifungal agents should not be used in the treatment with NAC species in dairy cows in Ningxia province of China, owing to the high drug resistance of these Candida species. Interestingly, these isolates were from animals that had not been treated with antifungal agents, suggesting that animal isolates were more exposed to anthropic environmental selective pressures, such as the use of azole antifungals in agricultural practices [33]. Therefore, a special attention must be paid to dairy products for monitoring the antifungal susceptibility of Candida spp. and other fungi recovered from animals is extremely important, since they may act as reservoirs of strains causing human disease and may present a risk for immunocompromised patients [34].

Previous reports indicated that a large number of virulent factors have been determined in $C$. krusei and $C$. parapsilosis, including the $\beta-1,3-D$-glucan synthase enzyme, aspartyl proteinases, the ATP binding cassette $(\mathrm{ABC})$ transporter, major facilitator superfamily (MFS) transporter, the zinc cluster transcription factor,14 $\alpha$-demethylase, efflux transporters. In the present study, we also observed that most of the C. krusei isolates harbored ERG11, ABC2 and FKS1 genes, and most of the C. parapsilosis isolates harbored genes of FKS1, FKS2, FKS3, SAPP1, SAPP2, ERG11, CDR1 and MDR1. The Fksp subunits of the $\beta-1,3-D$-glucan synthase enzyme are the target of echinocandins [35] and are encoded by the FKS1,FKS2, and FKS3 genes. Many reports indicated that a reduced-susceptibility (RES) to echinocandin was

Table 4 Results of antimicrobial susceptibility tests of C. parapsilosis isolates $(n=6)$

\begin{tabular}{lllll}
\hline Antibiotic & Resistant, \% (no.) & Intermediate, \% (no.) & Susceptible-dose dependent, SDD, \% (no.) & Susceptible, \% (no.) \\
\hline Amphotericin & $33.3(n=2)$ & 0 & $33.3(n=2)$ & $33.3(n=2)$ \\
Fluorocytosine & $100(n=6)$ & 0 & 0 & 0 \\
Fluconazole & 0 & 0 & 0 & $66.7(n=4)$ \\
Itraconazole & $33.3(n=2)$ & 0 & 0 & 0 \\
Ketoconazole & 0 & 0 & 0 & $100(n=6)$ \\
Nystatin & 0 & 0 & $(n=6)$ & $100(n=6)$ \\
\hline
\end{tabular}




\section{Field isolates}

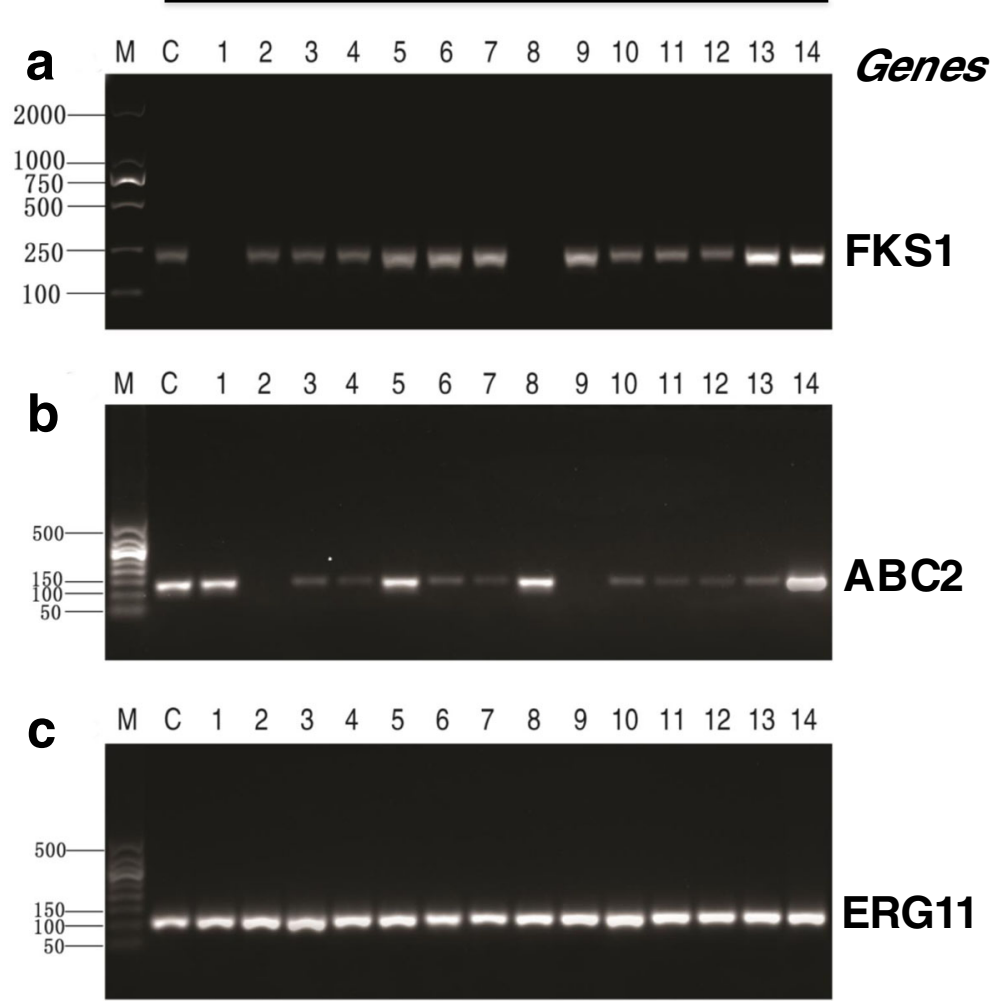

Fig. 3 Virulence-related genes of C. krusei isolates determined by PCR assay. The indicated virulence-related genes of (a) FSK1, b ABC2 and (c) EGR11 in 14 field C. krusei isolates of this report were detected by PCR assay. C, control C. krusei ATCC6258 strain; lanes 1 to 14 represented C. krusei isolate 1-14. M, 50 bp DNA ladders

associated with mutations in two conserved regions of fks1 and fks2, and amino acid substitutions in the proteins encoded by these genes were observed within two or three hot spot (HS) regions on each gene [36-38]. In the present study, FKS1, FKS2, and FKS3 genes were detected in all C. parapsilosis field isolates. 85.7\% (12/14) of $C$. krusei isolates were positive in FKS1 gene. Further studies are needed to confirm the mutation in hot spot (HS) regions on FKS1, FKS2 genes of C. krusei and C. parapsilosis, in order to elucidate the capability of the M27-A3 guidelines to detect the resistance to echinocandin. The secretion of aspartyl proteinases (Saps) has been considered as important elements of virulence for C. albicans [39], and it is also recognized as virulence factors for C. parapsilosis [40]. In C. parapsilosis, SAPP1, and SAPP2 are two annotated secreted aspartyl proteinase genes [41-43]. These enzymes are involved in providing nutrients for pathogen propagation, tissue colonization and further tissue invasion by rupturing host mucosal membranes [23]. In this study, $100 \%$ of $C$. parapsilosis isolates were found to carry SAPP1 and SAPP2 genes. This result was in agreement with previous reports [44].
The common mechanisms of Candida resistant to azoles include changes in target enzyme and upregulation of multidrug resistance protein (MDR). The target enzyme of azoles is $14 \alpha$-lanosterol demethylase (14-DM), which is responsible for the production of an ergosterol precursor and is encoded by the gene ERG11. In C. albicans and C. parapsilosis, the efflux pump genes associated with azole resistance include CDR1, CDR2, and MDR1 [45]. However, the drug-resistant genes in C. krusei are involved in $\mathrm{ABC} 1$ and ABC2 $[46,47]$. The results in this study also showed that $100 \%$ of C. parapsilosis isolates contained the CDR1 and ERG11 genes, and $66.7 \%$ of C. parapsilosis isolates contained the MDR1 gene. 100\% (14/14) of C. krusei isolates contained the ERG11 gene, and 85.7\% (12/14) of C. krusei isolates contained the $A B C 2$ gene, despite the $A B C 1$ gene was not detect in $C$. krusei. This finding was in line with previous studies in humans by $\mathrm{He}$ et al. that $\mathrm{ABC} 2 \mathrm{p}$ was suggested to play a more important role in the resistance of C. krusei to azoles, instead of ABC1p [46].

Taken together, it was demonstrated that C. krusei and C. parapsilosis isolates from mycotic mastitis were present in Yinchuan of Ningxia with a potential of multidrug resistance. Further studies are needed to confirm 


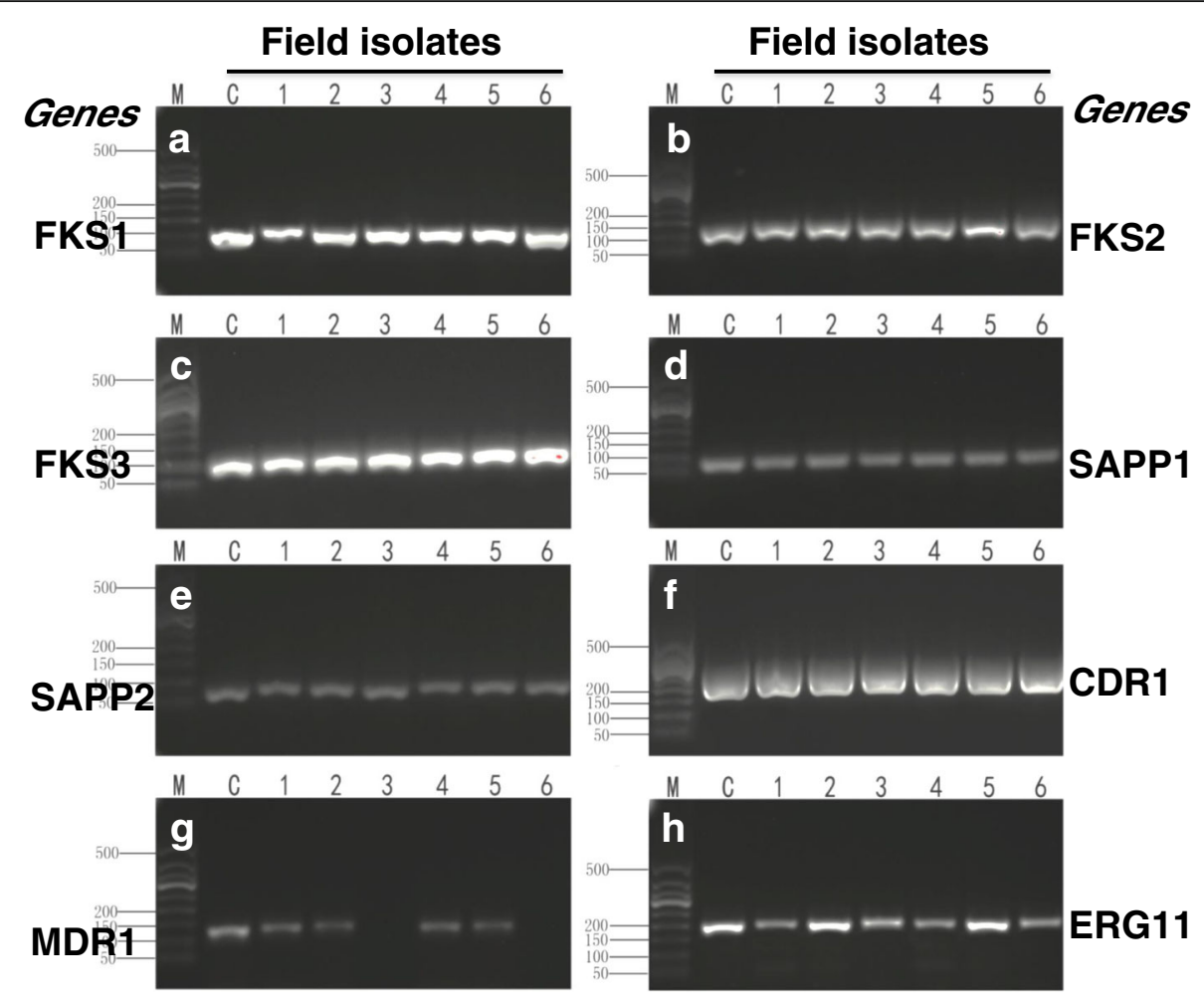

Fig. 4 Virulence-related genes of C. parapsilosis isolates determined by PCR assay. The indicated virulence-related genes of (a) FSK1, b FSK2, c FSK3 (d) SAPP1, e SAPP2, f CDR1, g MDR1 and (h) EGR11 in 6 field C. parapsilosis isolates of this report were detected by PCR assay. c, C. parapsilosis ATCC22019 control strain; lanes 1 to 6 represented C. parapsilosis isolate 1-6. M, 2 kb DNA ladders

mutations in ERG11, gain-of-function mutations in transcription factors, such as multidrug resistance regulator 1 (MRR1) and transcriptional activator of CDR gene 1 (TAC1), and the overexpression of these genes to elucidate the molecular mechanisms of resistance which caused by C. krusei and C. parapsilosis isolates from mycotic mastitis presented in Yinchuan, Ningxia of China.

\section{Conclusions}

A total of 60 isolates obtained from clinical mastitis milk samples in Yinchuan, Ningxia province of China were identified as Candida species according to phenotypic characteristics and MALDI-TOF MS. The most frequent Candida species found in this study was C. krusei, followed by $C$. parapsilosis. Other non-albicans Candida (NAC) species were also found in a low frequency. There was no Candida albicans was isolated in this study. According to results of this study, NAC may play an important pathogenic role in mycotic mastitis in dairy farms of Yinchuan region in Ningxia province of China. The $C$. krusei and $C$. parapsilosis displayed a strong antifungal resistance with drug-resistant genes. Most of C. krusei isolates harbored the ERG11, ABC2 and FKS1 genes, and most of the $C$. parapsilosis isolates harbored the FKS1, FKS2, FKS3, SAPP1, SAPP2, ERG11, CDR1 and MDR1 genes.

\section{Abbreviations}

14-DM: 14a-lanosterol demethylase (14-DM); ABC: ATP binding cassette; ATCC: American Type Culture Collection;; C.: Candida; CDR1: Candida drug resistance gene 1; CSH: Cell-surface hydrophobicity; ERG11: 14ademethylases; FKS: Fksp subunits of the $\beta$-1,3-D-glucan synthase enzyme; MALDI-TOF MS: Matrix-assisted laser desorption ionization-time of flight mass spectrometry; MDR1: Multiple drug resistance gene 1; MFS: Major facilitator superfamily; MRR1: Multidrug resistance regulator 1; NAC: Nonalbicans Candida; PCR: Polymerase chain reaction; SAP: Secreted aspartyl proteinase; ssp.: Species; TAC1: Transcriptional activator of CDR gene 1

\section{Acknowledgements}

The authors warmly thank to all study participants, owners of farms, veterinarians and personnel of the Center of Disease Control and Veterinary Institute in Ningxia Hui Autonomous Region of China, who helped in the realization of this study.

\section{Funding}

This study was supported by a grant from the National Natural Science Foundation of China (No.31660728), a grant from the project for the First-class discipline construction (Biology) of Ningxia Universities (NXYLXK2017B05), Major Innovation Projects for Building First-class Universities in Western China (ZKZD2017001) and a grant from Natural Science Foundation of Ningxia (NZ15017). These funding play no role in in the design of the study and collection, analysis, and interpretation of data and in writing the manuscript.

\section{Availability of data and materials}

All data generated or analyzed during this study are included in this published article.

Authors' contributions

$J D, Y W$ and XZ conceived and designed the experiments; JD and XW analyzed the data and drafted the manuscript; JD, HL, XL and JW performed experiments and acquired data; YW and XZ interpreted data and critically 
revised the manuscript. All authors read and approved the final version of the manuscript.

\section{Ethics approval and consent to participate}

This study was conducted in accordance with the Law on Animal Protection and Welfare of Ningxia Hui Autonomous Region of China. Samples were recovered after acquiring the permission from study participants. Since only the milk samples but not mammary tissues were harvested in this study, all owners of farmers who participated in this provided their verbal consent to participate in this study. This study was submitted to and approved by the Ethics Committee of Animal Study in Ningxia University.

\section{Consent for publication}

Not applicable.

\section{Competing interests}

The authors declare that they have no competing interests.

\section{Publisher's Note}

Springer Nature remains neutral with regard to jurisdictional claims in published maps and institutional affiliations.

\section{Author details}

${ }^{1}$ Key Laboratory of the Ministry of Education for the Conservation and Utilization of Special Biological Resources of Western China, Ningxia University, Yinchuan 750021, Ningxia, China. ${ }^{2}$ College of Life science, Ningxia University, Yinchuan 750021, Ningxia, China.

Received: 5 February 2018 Accepted: 8 August 2018 Published online: 29 August 2018

\section{References}

1. Costa EO, Ribeiro AR, Watanabe ET, Melville PA. Infectious bovine mastitis caused by environmental organisms. Zentralbl Veterinarmed B. 1998;45(2):65.

2. Dworeckakaszak B, Krutkiewicz A, Szopa D, Kleczkowski M, Biegańska M. High Prevalence of Candida Yeast in Milk Samples from Cows Suffering from Mastitis in Poland. Scientific World Journal. 2012;2012(1):196347.

3. Costa EO, Gandra CR, Pires MF, Coutinho SD, Castilho W, Teixeira CM. Survey of bovine mycotic mastitis in dairy herds in the state of Sao Paulo, Brazil. Mycopathologia. 1993;124(1):13-7.

4. De CSR, Marin JM. Isolation of Candida spp. from mastitic bovine milk in Brazil. Mycopathologia. 2005;159(2):251-3.

5. Pfaller MA, Houston, Coffmann. Application of CHROMagar Candida for rapid screening of clinical specimens for Candida albicans, Candida tropicalis, Candida krusei, and Candida (Torulopsis) glabrata. J Clin Microbiol. 1996:34(1):58-61.

6. CLSI. Method for antifungal disk diffusion susceptibility testing of yeasts; approved guideline. Wayne: Clinical and Laboratory Standards Institute; 2004.

7. CLSI. Zone diameter interpretive standards, corresponding minimal inhibitory concentration (MIC) interpretive breakpoints, and quality control limits for antifungal disk diffusion susceptibility testing of yeasts; informational supplement. 2nd ed. Wayne: Clinical and Laboratory Standards Institute; 2008

8. Odds FC, Bernaerts R. CHROMagar Candida, a new differential isolation medium for presumptive identification of clinically important Candida species. J Clin Microbiol. 1994;32(8):1923.

9. Seker E. Identification of Candida species isolated from bovine mastitic milk and their in vitro hemolytic activity in western Turkey. Mycopathologia. 2010;169(4):303-8

10. ErbaŞ G, Parin U, Kirkan S, SavaŞAn S, ÖZavci MV, YÜKsel HT. Identification of Candida strains with nested PCR in bovinemastitis and determination of antifungal susceptibilities. Turk J Vet Anim Sci. 2017;41:757-63.

11. Sartori LCA, Santos RC, Marin JM. Identification of Candida species isolated from cows suffering mastitis in four Brazilian states. Arquivo Brasileiro De Medicina Veterinária E Zootecnia. 2014;66(5):1615-7.

12. Pengov A. Prevalence of mycotic mastitis in cows. Acta Veterinaria. 2002; 52(2):133-6.

13. Ruz-Peres M, Benites NR, Yokoya E, Melville PA. Resistência de fungos filamentosos e leveduras isolados de leite CRU bovino à pasteurização e fervura. Vet Zootec. 2010;17(1):62-70.
14. Ksouri S, Djebir S, Hadef Y, Benakhla A. Survey of bovine mycotic mastitis in different mammary gland statuses in two north-eastern regions of Algeria. Mycopathologia. 2015;179(3-4):327-31.

15. Krukowski H, Tietze M, Majewski T, Różański P. Survey of yeast mastitis in dairy herds of small-type farms in the Lublin region, Poland. Mycopathologia. 2001;150(1):5-7.

16. Eldesouky I, Mohamed N, Khalaf D, Salama A, Elsify A, Ombarak R, Elballal S, Effat M, Alshabrawy M. Candida mastitis in dairy cattle with molecular detection of Candida albicans. Kafkas Üniversitesi Veteriner FakÜltesi Dergisi. 2016;22(3):461-4.

17. Costa GMD, Silva ND, Rosa CA, Pereira UDP. Mastite por leveduras em bovinos leiteiros do Sul do Estado de Minas Gerais, Brasil mastitis caused by yeasts in dairy herds in the south of the Minas Gerais state, Brazil. Ciência Rural. 2008;38(7):1938-42.

18. Fadda ME, Pisano MB, Scaccabarozzi L, Mossa V, Deplano M, Moroni P, Liciardi M, Cosentino S. Use of PCR-restriction fragment length polymorphism analysis for identification of yeast species isolated from bovine intramammary infection. J Dairy Sci. 2013;96(12):7692.

19. Zaragoza CS, Olivares RA, Watty AE, Moctezuma Ade L, Tanaca LV. Yeasts isolation from bovine mammary glands under different mastitis status in the Mexican high Plateu. Revista iberoamericana de micologia. 2011;28(2):79-82

20. Elad D, Shpigel NY, Winkler M, Klinger I, Fuchs V, Saran A, Faingold D. Feed contamination with Candida krusei as a probable source of mycotic mastitis in dairy cows. J Am Vet Med Assoc. 1995;207(5):620.

21. Freydiere AM, Guinet R, Boiron P. Yeast identification in the clinical microbiology laboratory: phenotypical methods. Med Mycol. 2001;39(1):9.

22. Pfaller MA, Andes DR, Diekema DJ, Horn DL, Reboli AC, Rotstein C, Franks B, Azie NE. Epidemiology and outcomes of invasive candidiasis due to non-albicans species of Candida in 2,496 patients: data from the prospective antifungal therapy (PATH) registry 2004-2008. PLoS One. 2014;9(7):e101510.

23. Trofa D, Gacser A, Nosanchuk JD. Candida parapsilosis, an emerging fungal pathogen. Clin Microbiol Rev. 2008;21(4):606-25.

24. Kuhn DM. Comparison of biofilms formed by Candidaalbicans and Candidaparapsilosis on bioprosthetic surfaces. Infect Immun. 2002;70(2): 878-88

25. Panagoda GJ, Ellepola AN, Samaranayake LP. Adhesion of Candida parapsilosis to epithelial and acrylic surfaces correlates with cell surface hydrophobicity. Mycoses. 2001;44(1-2):29.

26. Spanamberg A, Jr WE, Brayer Pereira DI, Argenta J, Cavallini Sanches EM, Valente P. Ferreiro L. Diversity of yeasts from bovine mastitis in southern Brazil. Revista iberoamericana de micologia. 2008;25(3):154-6.

27. Rodríguez D, Almirante B, Cuenca-Estrella M, Rodríguez-Tudela JL, Mensa J, Ayats J, Sanchez F, Pahissa A. Predictors of candidaemia caused by nonalbicans Candida species: results of a population-based surveillance in Barcelona, Spain. Clin Microbiol Infect. 2010;16(11):1676.

28. Sonmez M, Erbas G. Isolation and identification of Candida spp. from mastitis cattle milk and determination of antifungal susceptibilities. Int J Vet Sci. 2017;6(2):104-7.

29. Tavanti A, Hensgens LA, Mogavero S, Majoros L, Senesi S, Campa M. Genotypic and phenotypic properties of Candida parapsilosis sensu strictu strains isolated from different geographic regions and body sites. BMC Microbiol. 2010;10(1):1-11.

30. Wawron W, Bochniarz M, Dabrowski R. Antifungal susceptibility of yeasts isolated from secrection of inflamed mammary glands in cows. Pol J Vet Sci. 2010;13(3):487-90.

31. Xiao M, Fan X, Chen SC, Wang H, Sun ZY, Liao K, Chen SL, Yan Y, Kang M, Hu ZD. Antifungal susceptibilities of Candida glabrata species complex, Candida krusei, Candida parapsilosis species complex and Candida tropicalis causing invasive candidiasis in China: 3 year national surveillance. I Antimicrob Chemother. 2015;70(3):802.

32. Gunes I, Kalkanci A, Kustimur S. Comparison of three different commercial kits with conventional methods for the identification of Candida strains to species level. Mikrobiyoloji Bulteni. 2001;35(4):559-64.

33. Rocha MF, Alencar LP, Paiva MA, Melo LM, Bandeira SP, Ponte YB, Sales JA, Guedes GM, Castelo-Branco DS, Bandeira TJ, et al. Cross-resistance to fluconazole induced by exposure to the agricultural azole tetraconazole: an environmental resistance school? Mycoses. 2016;59(5):281-90.

34. Edelmann A, Krüger M, Schmid J. Genetic relationship between human and animal isolates of Candida albicans. J Clin Microbiol. 2005;43(12):6164-6. 
35. Douglas CM, D'lppolito JA, Shei GJ, Meinz M, Onishi J, Marrinan JA, Li W, Abruzzo GK, Flattery A, Bartizal K. Identification of the FKS1 gene of Candida albicans as the essential target of 1,3-beta-D-glucan synthase inhibitors. Antimicrob Agents Chemother. 1997;41(11):2471.

36. Garcia-Effron G, Katiyar SK, Park S, Edlind TD, Perlin DS. A naturally occurring proline-to-alanine amino acid change in Fks1p in Candida parapsilosis, Candida orthopsilosis, and Candida metapsilosis accounts for reduced echinocandin susceptibility. Antimicrob Agents Chemother. 2008;52(7):2305.

37. Martícarrizosa M, Sánchezreus F, March F, Cantón E, Coll P. Implication of Candida parapsilosis FKS1 and FKS2 mutations in reduced Echinocandin susceptibility. Antimicrob Agents Chemother. 2015;59(6):3570-3.

38. Prigitano A, Esposito MC, Cogliati M, Pitzurra L, Santamaria C, Tortorano AM. Acquired echinocandin resistance in a Candida krusei blood isolate confirmed by mutations in the fks1 gene. New Microbiol. 2014;37(2):237-40.

39. Naglik JR, Challacombe SJ, Hube B. Candida albicans secreted Aspartyl proteinases in virulence and pathogenesis. Microbiol Mol Biol Rev. 2003;67(3):400.

40. Horváth P, Nosanchuk JD, Hamari Z, Vágvölgyi C, Gácser A. The identification of gene duplication and the role of secreted aspartyl proteinase 1 in Candida parapsilosis virulence. J Infect Dis. 2012;205(6):923.

41. Dostál J, Dlouhá H, Malon P, Pichová I, Hrusková-Heidingsfeldová O. The precursor of secreted aspartic proteinase Sapp 1p from Candida parapsilosis can be activated both autocatalytically and by a membrane-bound processing proteinase. Biol Chem. 2005;386(8):791.

42. Merkerová M, Dostál J, Hradilek M, Pichová I. Cloning and characterization of Sapp $2 p$, the second aspartic proteinase isoenzyme from Candida parapsilosis. FEMS Yeast Res. 2006;6(7):1018-26.

43. Hrusková-Heidingsfeldová O, Dostál J, Majer F, Havlíkova J, Hradilek M, Pichová I. Two aspartic proteinases secreted by the pathogenic yeast Candida parapsilosis differ in expression pattern and catalytic properties. Biol Chem. 2009;390(3):259-68.

44. Dabiri S, Shams-Ghahfarokhi M, Razzaghi-Abyaneh M. SAP(1-3) gene expression in high proteinase producer Candida species strains isolated from Iranian patients with different Candidosis. J Pure Appl Microbiol. 2016;10(3):1891-6.

45. Chen LM, Xu YH, Zhou CL, Zhao J, Li CY, Wang R. Overexpression of CDR1 and CDR2 genes plays an important role in fluconazole resistance in Candida albicans with G487T and T916C mutations. J Int Med Res. 2010;38(2):536.

46. He X, Zhao M, Chen J, Wu R, Zhang J, Cui R, Jiang Y, Chen J, Cao X, Xing Y. Overexpression of both ERG11 and $A B C 2$ genes might be responsible for Itraconazole resistance in clinical isolates of Candida krusei. PLoS One. 2015; 10(8):e0136185.

47. Katiyar SK, Edlind TD. Identification and expression of multidrug resistance-related ABC transporter genes in Candida krusei. Med Mycol. 2001;39(39):109-16.

Ready to submit your research? Choose BMC and benefit from:

- fast, convenient online submission

- thorough peer review by experienced researchers in your field

- rapid publication on acceptance

- support for research data, including large and complex data types

- gold Open Access which fosters wider collaboration and increased citations

- maximum visibility for your research: over $100 \mathrm{M}$ website views per year

At BMC, research is always in progress.

Learn more biomedcentral.com/submissions 